\title{
Between Street Demonstrations and Ballot Box: Tenure Rights, Elections, and Social Movements among the Urban Poor in Jakarta
}

\author{
Amalinda Savirani ${ }^{1}$ and Guntoro ${ }^{2}$
}

Received: 20 February 2020 | Accepted: 15 May 2020 | Published: 10 June 2020

\begin{abstract}
This article investigates the political participation of urban poor through the People's Network of Urban Poor (Jaringan Rakyat Miskin Kota, JRMK) in Jakarta's 2017 gubernatorial election. It also traces the material aspects of this movement, particularly the issues emphasised by the movement: settlement rights, tenure rights, and livelihood rights. Settlement rights reflect a complex system of agrarian laws in Indonesia, and urban development plans in Jakarta, all of which have been shaped by the contestation of economic and political interests. Tenure and livelihood rights for the urban poor, are heavily steeped in history, with constant threat of forced eviction, As a result the three rights became increasingly tangible and movement became ever more urgent. This article argues that the materiality of social movements influences the urban poor movement political strategies. In this case, the movement created a "political contract" with the candidate who ultimately emerged victorious in the election; owing to the complexity of land and settlement issues, electoral politics offered the most promising strategy. However, movements with different types of 'materiality' could employ other approaches.
\end{abstract}

Keywords: Jakarta urban poor, political contract, housing rights

\section{Introduction}

Social movements are always influenced by their own material aspects, including the type of the issue being advocated, the urgency of this issue, the threat posed by this issue, and the political networks employed by the movement. As such, social movements have different tendencies and strategies. This article examines one political movement through which Jakarta's urban poor have advocated for affordable housing by organising and mobilising themselves during Jakarta's 2017 gubernatorial election, through signing a "political contract" with a candidate. The movement began in the lead-up to voting, and continued until after the supported candidate's election. This

\footnotetext{
${ }^{1}$ Lecturer at Department of Politics and Government Faculty of Social and Political Science, Universitas Gadjah Mada.
}

${ }^{2}$ Social activist at Urban Poor Consortium, Jakarta. 
article seeks to answer several questions: how did the material aspects of the movement (i.e. settlement and livelihood rights) influence its strategies in Jakarta? How were the material aspects of the movement incorporated into its organisational format and strategies? What were the results of the movement, and to what extend did the movement promote members' rights? In order to answer these questions, this article is divided into several sections. The first maps the political participation of Jakarta's urban poor; the second presents the history of the movement; the third discusses the fundamental issues experienced by Jakarta's urban poor, including the scarcity of housing and other issues that influence their livelihood; the fourth offers a conclusion, describing the process through which the political contract was signed.

\section{Political Participation, Urban Poor, Elections, and Social Movements}

Many scholars have examined the political participation of the urban poor in democracies. Joan Nelson (1979), for example, investigated the activities of urban poor in developing countries, identifying four categories: a) vertically mobilised participation; b) ethnic association participation; c) special interest groups; and d) participation generated by working class-oriented political parties. This article refers primarily to the third and fourth categories, focusing on the agendas promoted and those promoting these agendas.

Nelson also argues that political participation is intended primarily to promote empowerment and active involvement; create collective action to identify community issues; promote change; guarantee voters' right to be involved in decision-making processes that affect them; and create social justice and equality without social or structural discrimination (Nelson, 1979, p. 11). All of these goals are inexorably interrelated.

Such views of political participation operate at the individual level, viewing it as being created through an individual desire to promote change. In many cases, however, the political participation amongst the urban poor is not an individual affair, as they enjoy a high level of collectivism and lack the agency to individually promote change (Harriss, 2005). Several scholars have argued that the urban poor have lower levels of political participation than the middle classes, as the former must dedicate their time to fulfilling their everyday needs while the latter have free time with which they can become politically active (Weeks, 2014).

Within the context of elections, there are two related views of the participation of urban poor. First, scholars have argued that the urban poor-owing to their poverty-are vulnerable to the practice of patronage, especially in "one man, one vote" systems. Direct democratic systems are argued to have promoted vote buying around the globe, including in Indonesia (Aspinall and Sukmajati, 2014) and the Philippines (Hutchison, 2007). Such studies argue that the urban poor become politically active for short-term benefits: receiving money in exchange for their votes, thereby establishing opportunistic and mutually beneficial relationships with their representatives. However, such interactions do not occur within a "citizenship" framework, wherein voters' democratic rights are recognised by their elected representatives and enjoy access 
to public services (see Berenschot, 2018 in India; Banks, 2008 in Bangladesh).

Other scholars, however, have argued the opposite: poverty can ensure that voters reject money politics, instead creating consolidated and collective movements that advocate for new policy (Lawless \& Fox, 2001). Voters thus organise themselves to create awareness of the rights being violated. Ahuja and Chibber (2012, p. 1) state, "Voting is important. If I don't vote, I am dead to the state." The civil society organisation Basti Basheer Odhikar Surakha Committee (BOSC), for instance, organised the urban poor in Dhaka, Bangladesh, to create collective participation and successfully connected them with government projects targeted at them. BOSC thereby created awareness among the urban poor. However, this organisation was limited to the local level, being unable to expand to the national level or ensure actors' commitment. Ahuja and Chibber (2012) add that elections offer voters a moment for consolidating the urban poor and organising them to promote collective goals.

In Indonesia, the political system has not only been shaped by paternalistic practices, but also by the organisation of the urban poor. Gibbings et al. (2017), for instance, describe a "political contract" between a candidate in Yogyakarta's 2012 mayoral election and street merchants. Savirani and Aspinall (2018) identify a similar political contract signed between Jakarta's urban poor and a candidate in the capital's 2017 gubernatorial election. Labourers in Karawang (Caraway dan Ford, 2014) and Batam (Ford, 2014) have used a similar mechanism.

From these studies, particularly those regarding the organisation of the urban poor during elections, it may be concluded that they are closely related. McAdam and Tarrow (2010) argue that it is necessary to combine studies of social movements and electoral politics to understand how social movements influence elections. All elections involve the mobilisation of voters, be it by candidates, campaign teams, or social movements. Within the context of social movements and their interactions with political parties and actors during elections, McAdam and Tarrow (2010, pp. 533-534) identify linkages as being created through six mechanisms. First, social movements may introduce new approaches to collective action that influence campaign activities. Second, social movements may establish electoral coalitions or even become political parties themselves. Third, social movements may be proactively involved in mobilising voters, finding opportunities to incorporate their agendas into elections. Fourth, social movements may be reactively involved in electoral mobilisation, increasing the scale and intensity of their actions while opposing dishonest electoral activities. Fifth, social movements may join political parties and polarise them from within. Sixth, social movements may transform existing electoral systems. Other authors, such as Tomsa and Setijadi (2018), have also examined the link between the urban poor and elections and labelled these movements as "electoral movements" (2018, p. 558)

In the context of this article, and referencing the definitions offered by McAdam and Tarrow, social movements may be identified as falling into the first and third categories. Social movements used the 2017 Jakarta gubernatorial election as an opportunity to promote their agenda and promote members' settlement and livelihood rights. At the same time, they 
introduced a new approach to elections, no longer accepting vote buying but attempting to transform the situation through collective action. This election was a golden opportunity for the urban poor to promote their collective agenda and guarantee access to appropriate housing and livelihoods. For this, they organised themselves before the election and offered their votes to candidates in exchange for the fulfilment of their demands.

\section{History of Urban Poor Movements in Jakarta}

The grassroots organisation discussed in this article is the Jakarta branch of the People's Network of Urban Poor (Jaringan Rakyat Miskin Kota, JRMK). This organisation is a subsidiary of the Urban Poor Consortium (UPC), established in September 1997 when Jakarta was under the leadership of General Sutiyoso. At the time, Indonesia's political system was an authoritarian and repressive one. UPC had an ideology that was radical for the time, positioning the urban poor-rather than the elites-as central to political change. This ideology underpinned all of its advocacy activities, which dealt not only with political rights but also housing rights, employment rights, settlement rights, and livelihood rights. Through these activities, it improved the capacity of the urban poor.

Since its establishment, UPC has organised 58 kampungs in Jakarta. It has also organised various grassroots movements, mobilised pedicab drivers and street merchants, and created employment opportunities. In order to improve the confidence of the urban poor and mitigate the government's discursive dominance, in 1997 UPC backed a pedicab driver named Rasdullah as its gubernatorial candidate (at the time, the governor was selected by members of the Jakarta Provincial Parliament). The public mocked this candidate, and ultimately Rasdullah as he failed to meet administrative requirements (Steijlen, 2004).

UPC expanded to the national organisation through UPLINK, the Urban Poor Linkage, which had branches in nine Indonesian cities: Aceh, Lampung, Jakarta, Yogyakarta, Surabaya, Sidoarjo, Makassar, Kendari, and Palu. This network, which was renamed to JRMK in 2002, attempted to promote policy reform through various means. For example, it became involved in electoral politics and conducted negotiations with gubernatorial, mayoral, and regent (bupati) candidates. In 2009, the Makassar Committee for the People's Struggle (Komite Perjuangan Rakyat Makassar, KPRM)-a branch of UPLINKsigned a political contract with mayoral candidate Ilham Arief Siradjudin (Aco) and his deputy Supomo Guntur. The candidates promised that they would put a stop to forced evictions, improve land security, reform healthcare policy, create jobs, guarantee the wellbeing and prosperity of the urban poor, and involve them in decision-making processes. In return, KPRM would mobilise voters. Ultimately, the organisation was able to gather 65,000 votes for Aco and Guntur, who won the election (Power from below, 2017).

In Indonesia, political deals between voters and candidates (both executive and legislative) are popularly known as "political contracts". Amongst both citizens and politicians, this approach is a popular means of advocating for their interests (for the former) and gathering support (for the latter). Gibbings et al. (2017) define "political contracts" as a mechanism for ensuring accountability, one that is superior 
to vote buying (where the transaction is dominated by one party). Political contracts are oriented towards long-term goals, while vote-buying involves 'on the spot transactions'.

Such a long-term political strategy was incorporated in the political contract between the urban poor and candidates in Jakarta's 2017 gubernatorial election. This political contract enabled UPC to advocate for long-term programmes that promoted the interests of the urban poor, including their housing rights. Such contracts had been used in previous gubernatorial elections. In 2007, for example, UPC had backed a Prosperous Justice Party candidate, Adang Daradjatun, who ultimately lost the election. In 2012, UPC had signed a political contract with Joko Widodo, who won the election. However, when forced evictions continued under Widodo (and, after his election as president, his deputy Basuki Tjahaja Purnama), UPC decided to back a new candidate. Learning from the previous election, wherein the political contract was violated, it made a clearer agreement (one based on legal documents) in the hopes that its contract would not be violated.

One candidate in Jakarta's 2017 gubernatorial election was the incumbent, Basuki Tjahaja Purnama (popularly known as Ahok), who had been involved in a wave of forced evictions between 2015 and 2016. UPC expected that, if Ahok were elected, these evictions would continue. The threat of eviction was thus one material aspect of the movement and its political contract. Another material aspect was housing, a fundamental human need without which people could have no livelihood and could not survive. Furthermore, every parcel of land in Jakarta is an important and valuable material resource, and as such desired by those with significant economic and political capital (Savirani, 2017; Arai, 2015).

\section{Poverty, Housing Shortages, and Housing Policy}

Jakarta is home to more than 380,000 urban poor. At the national level, some 28 million Indonesians $(10.86 \%$ of the population) live below the poverty line; it may thus be concluded that poverty in Jakarta is not as rampant as in more rural areas. Experts have shown that urban and rural communities experience poverty differently, with the urban poor exhibiting more indicators of poverty than the rural poor (Baharoglu \& Kessides, 2002). As such, it is more difficult to be poor in the city.

One significant issue for the urban poor, including those in Jakarta, is housing security. Many city residents live on land that does not legally belong to them, occupying what are known as "informal settlements"; these must not be confused with "illegal settlements", as even though residents occupy land that does not legally belong to them, they are still part of informal communities that are created by members. Problematically, as urban migration continues and populations grow, the availability of housing-especially affordable housing-remains the same. This limited supply of housing has been problematic since the colonial era, and has remained unsolved since independence (Abeyasekere, 1989, p. 81).

At the national level, the Indonesian government has only been able to meet $30 \%$ of the demand for housing; in March 2019, there was a need for 7.6 million houses (Hutapea, 2019). Some $75 \%$ of Indonesians fulfil their own need for 
housing, using what have often been identified as "self-help" mechanisms (Tunas \& Peresthu 2009). Four types of self-help mechanisms may be identified. First, people may purchase homes in middle-class housing developments in more affordable cities such as Tangerang and Bekasi (Winarso, 1999). Second, people may build their homes in areas that have been zoned for housing, but have yet to be developed; land ownership may be proven with a verponding, a colonial-era document. Third, people may build their homes on government-owned land and use it under land-usage rights (hak guna bangunan, HGB). Fourth, people may live upon the land owned by others, and thus leave themselves vulnerable to forced eviction. Most urban poor utilise the third and fourth strategies.

The Indonesian government has passed several policies in order to solve this housing problem. In October 2004, for instance, President Susilo Bambang Yudhoyono passed a policy that sought to build one million homes by 2020 for families with an income of Rp 1.5 million/month; this would include 200,000 simple healthy homes (rumah sehat sederhana, RSS) and 14,000 subsidised apartments (Kusno, 2012). Vice President Jusuf Kalla later transformed this policy into the 1,000 Towers Programme, with most homes being constructed in Jakarta and intended for two million lowincome families. Ultimately, however, this goal was not realised and the programme was unable to resolve the housing crisis. Rather, it benefitted the urban middle classes, as developers preferred to rent or sell their units to middle-class families who

\footnotetext{
${ }^{3}$ Interview with $\mathrm{M}$, resident of Pluit Reservoir.
}

offered them greater opportunities for profit (Kusno, 2012).

Joko Widodo, while serving as the governor of Jakarta, also attempted to resolve the housing situation through an insitu upgrading approach (i.e. by repairing or renovating existing homes). This programme, titled "Kampung Deret", was most successfully implemented in Petogogan, South Jakarta (Dewi, 2014), but ultimately discontinued because an audit found that the land ownership was unclear; to use government funds, clear ownership was required.

At the same time, the urban poor were disproportionately affected by floods. Many lived along Jakarta's rivers and canals, and their settlements contributed to the narrowing of these waterways and thus to flooding. As such, Widodo sought to revitalise the Pluit Reservoir in North Jakarta, relocating 35,000 residents to the newly constructed Muara Baru Tower (Penggusuran waduk, 2013). UPC/JRMK was involved in the negotiation process, promoting a geser bukan gusur (relocate, not evict) approach; these organisations argued that apartment towers had to be completed before relocation began, and that residents should be directly involved in relocation. One resident stated that he had received the key to his new apartment before his home was demolished (Personal communication, March 27, 2015) ${ }^{3}$.

When Widodo was elected President of Indonesia in 2014, his deputy Basuki Tjahaja Purnama (Ahok) replaced him as acting governor. Under his leadership, forced evictions were common. Data from the Legal Aid Institute (Lembaga Bantuan Hukum, LBH) indicates that more than 
16,000 individuals were evicted by the Ahok government (LBH Jakarta, 2017). JRMK thus feared that, were Ahok re-elected, these evictions would continue and affect its members.

As justification for these evictions, the Ahok government cited violations of Bylaw No. 1 of 2012 regarding Regional Development Planning and Bylaw No. 1 of 2014 regarding Spatial Planning and Zonation. These policies identified specific parts of Jakarta, including riverbanks, as greenbelts that promote water absorption. Problematically, however, said areas were also used for middle-class settlements where evictions did not occur. Several commercial centres, including the Taman Anggrek, Kemang, Senayan, and Pantai Indah Kapuk malls, were also built on greenbelts and continued to operate (Ramadhiani, 2017). A dormitory for Universitas Bunda Mulia (UBM) students in North Jakarta was built in a white zone (dedicated for inspection roads) but never evicted. These zoning laws, thus, were violated by both the poor and the middle classes; however, the latter never faced any repercussions.

The urban poor network never wanted Ahok to be a governor again, because they will be a target for eviction. To do this, JRMK gained support from civil society organization that assisted them to connect with candidates. Four civil society groups were involved in the process: the Rujak Centre for Urban Studies (RCUS); students and lecturers at the Department of Architecture, University of Indonesia; Architecture Empowerment and Facilitation (ASF), and journalists. JRMK also received data regarding land and housing issues, campaigned for the housing rights of members, and offered alternative discourses regarding poverty and environmental disasters.

\section{A Political Contract through Voter Organisation}

First Round

Jakarta's 2017 gubernatorial election was contested by three candidates: Basuki Tjahaja Purnama (Ahok), Anies Baswedan, and Agus Harimurti Yudhoyono. In the first round, these candidates received $42.9 \%$, $39.9 \%$, and $17.2 \%$ of the vote, respectively. As such, Ahok and Anies went on to the second round, during which JRMK signed its contract with Anies Baswedan.

In the first round, JRMK had allowed members to vote for whomever they pleased, so long as they did not support Ahok. In the lead-up to the second round of voting, the organisation began communicating with Ahok's expected opponent, Anies Baswedan. During a meeting with representatives in October 2016, JRMK identified the organisation and candidate as sharing three principles: development need not involve eviction; houses are not mere homes, but sources of livelihood; and eviction has significant detrimental effects on residents' lives and livelihoods. The organisation and candidate agreed that livelihood security was an integral part of housing security, especially for informal labourers such as street vendors and pedicab drivers. During the meeting, Anies Baswedan stated that he would sign a political contract with JRMK if the organisation gave him its formal support.

In order to achieve its practical goal of promoting housing security, JRMK had begun organising its members during the first round of voting. Members were asked to come to their communities, visit street 
vendors, and use social media to spread the message "Evict Ahok in the First Round". JRMK members served as unpaid witnesses and election monitors in their villages, seeking to ensure fair and honest elections.

Such organisational activities continued during the second round of voting, when JRMK focused on 125 polling places in 40 communities; some of these polling places were in members' kampung, while others were in new communities. JRMK spoke with local communities, attempting to convince them to join the political contract. Ultimately, 31 communities-26 kampungs, 1 apartment tower, 3 street vendor groups, and 1 pedicab driver group-agreed to sign the contract. In 9 communities, leaders refused to sign the contract, believing that they were able to access candidates through their political parties, campaign teams, or volunteer organisations (Dedi ${ }^{4}$, personal communication, April 1, 2019).

In some kampung, residents joined even though their leaders were unwilling. In other kampung, leaders agreed to join but lacked the ability to consolidate residents. Owing to time constraints, JRMK allowed residents to choose whether or not they would join the political contract, so long as the decision was made democratically. Many kampungs signed the political contract owing to residents' own initiatives, rather than under the instruction of their formal leaders. Local residents sought to gather the support of their neighbours and make joint decisions. In other words, a bottom up approach-rather than a topdown one-was used to attract support. People who perceived their fates as being at stake in the gubernatorial election

\footnotetext{
4 Tongkol Kampung coordinator.
}

sought to organise their neighbours; they did not simply obey the instructions of their elites or leaders.

In mobilising others, individuals used their personal funds to cover their expenses, including food and gasoline (Eny ${ }^{5}$, personal communication, August 11, 2017). JRMK refused all forms of financial support, as by doing so it positioned itself as equal to its favoured candidate. Other expenses were covered through money collected from members during regular meetings; at each meeting, members were expected to contribute Rp 15,000 to cover the cost of food, snacks, and drinks. Local residents contributed their labour and energy to cook for these meetings. The printing and duplication of materials, meanwhile, was funded through contributions from participating kampung. Members thus funded the entire movement by themselves, despite their everyday economic difficulties.

\section{Second Round}

Before the second round, organisational activities intensified. Community members held a series of meetings between May and June 2015, distributing a list of the political promises broken by Ahok and attempting to consolidate voters. For example, in Lodana kampung in Ancol, North Jakarta-the regional coordinator Dedi explained to members the potential consequences of Ahok's re-election (Dedi, personal communication, April 2, 2019). Local residents believed that their collective fate depended on the results of the gubernatorial election. Meanwhile, in Kali Apuran, West Jakarta, a series of meetings

\footnotetext{
${ }^{5}$ JRMK coordinator.
} 
were held (Pras ${ }^{6}$, personal communication, April 1, 2019)

Political communication was also conducted with Anies Baswedan's campaign team. Working with one campaign staff tasked with handling programmes, JRMK drafted a political contract in March 2017. RCUS presented evidence-based data and information, including studies of legal instruments, to argue in favour of settlement rights. Both JRMK and the campaign staff agreed that land was not merely an asset, but also a production tool, and thus needed to be protected.

Pursuant to the terms of the political contract, JRMK and its members would support Anies Baswedan and his running mate Sandiago Uno, while the candidates would fulfil their political promises. JRMK promised an Anies victory in 125 specific polling places throughout Jakarta, offering voter support in exchange for political promises. This was received positively by the campaign staff, who appreciated the specificity of the offer; most contracts to that point had merely offered a non-specific commitment of voter support. Both parties agreed that, if these commitments went unfulfilled, both parties would attempt mediation and arbitration. If this failed, only then would the breach of contract be brought to court. At the end of the meeting, a nineteen-page draft was printed and distributed, with a promise to discuss specific issues after the governor and his staff had examined the contract. Ultimately, the political contract was signed on 8 April 2018 in Muka, a kampung in North Jakarta.

\section{Collaborations with civil society}

${ }^{6}$ Kali Apuran Kampung activist.
As stated above, elements of civil society were also involved in JRMK's social movement. Ensuring high levels of participation required significant knowledge of administrative and technocratic affairs, as well as powerful and passionate advocacy. As such, the social movement required the support of various parties to achieve its goals. The urban poor were thus supported by various organisations involved in urban development.

RCUS, UI, and ASF all supported members in their mapping and evaluation of spatial planning policies in Jakarta, including the Law on Spatial Planning, the Bylaw on Regional Spatial Planning, the Bylaw on Spatial Planning and Zonation, and the Bylaw on Public Order. Other legal practitioners voluntarily used their time to clarify existing laws. At the same time, referring to available data, these civil society elements sought to educate voters about their rights, including the various land rights, certificates, taxation, and payment receipts.

Academics with a background in law helped members prepare a formal political contract (informal communication with a lecturer at the Jentera Legal School, Jakarta, July 2018). Junior lecturers at the Department of Architecture, University of Indonesia, as well as participants in the Indonesian Architecture Students Congress (TKIMAI), worked to gather data; Lab Tanya, ASF, "Kampung Kota Merekam", and "Islam Bergerak" similarly contributed to the movement in their own ways. Also contributing to this movement were journalists from various media in Jakarta, who volunteered their free time to support the movement (Siti May, personal 
communication, April, 2, 2019) by working with local youths to gather and report information. Data were published online through https://medium.com/kampungkota-merekam.

\section{Contents and Legal Aspects of the Political Contract}

There is no universal academic definition of "political contract", as the concept is heavily informed by the Indonesian electoral context. Most relevant literature deals with citizen charters, particularly as related to public services. In such agreements, residents pressure the state to fulfil its obligation to provide basic public services. When agreements are reached during elections, they may be identified as "political contracts" between candidates and voters. Such political contracts are not legal documents, and as such they are not legally binding. The Indonesian legal system only recognises the validity of contracts that conform with the third volume of the Indonesian Legal Code, and as such political contracts have no basis in positive law, and are thus simply informal agreements. Where their points are violated, or their terms are breached, legal sanctions cannot be readily imposed.

This was seen in Jakarta's 2012 gubernatorial election, during which JRMK had signed a political contract with Joko Widodo and Basuki Tjahaja Purnama. When the terms of this contract were breached, JRMK had had no legal recourse, and was thus limited to using informal mechanisms such as demonstrations, audiences, mass media campaigns, and lobbying. These mechanisms were ultimately ineffective, and forced evictions continued unimpeded.
Learning from these experiences, JRMK had created a legally binding contract, one that offered a legal recourse in case its terms were breached. This was realised through several aspects of the contract: a) it involved an agreement between all involved parties; b) all involved parties had the capacity to enter a contract, and c) it identified specific terms and issues, rather than general prohibitions. These aspects were studied in detail by JRMK as well as its academic allies, with knowledge then being distributed to members through meetings. In principle, a political contract is an agreement, and in order to have legal force it must fulfil the requirements specified in the Indonesian Legal Code. In this case, JRMK experimented by creating a political contract that resembled a legal document, even though there was little chance it would be legally binding (Legal Aid Institute activist, personal communication, July 21 , 2017).

In its content, this contract was essentially the same as the one signed in 2012. This contract differed mainly in the level of detail it provided as well as its legalistic format. This document clearly identified its signatories, their kampung, and the locations affected. Before being identified in the contract, the organisation ensured that each kampung conformed with the applicable zoning law and the National Land Agency's online map.

Where kampungs failed to comply with applicable law, negotiations were conducted. For instance, the kampung of Lodan in North Jakarta sat upon a 15-metre wide strip of land that was zoned for an inspection road; as such, JRMK suggested that the road be reduced in width. Similar proposals were put forth by knowledgeable civil society elements, with the expectation 
that each proposal meet three criteria: first, residents' right to land, housing, employment, and livelihoods must be protected; second, proposals could not exceed the authority of the governor; and, third, proposals could not violate applicable law. All proposals were finalised by the campaign team before being included in the draft.

\section{Breaking Through the State}

$\begin{array}{ccc}\text { Anies } & \begin{array}{c}\text { Baswedan won the } \\ \text { election, receiving }\end{array}\end{array}$
approximately $58 \%$ of the vote. JRMK soon began monitoring the implementation of its political contract. This was critical, as it was possible that the new governor would attempt to breach the contract or break his promises-as had occurred after the 2012 Jakarta gubernatorial election, 2014 Presidential election, and elsewhere. Monitoring was thus no less important than organising voters.

During this stage, JRMK's activities differed significantly than before the election. Before the election, the movement had sought to organise voters and prepare strategies for implementing promises. As such, its greatest challenge had come from voters who refused to support its favoured candidate. After the election, however, JRMK's greatest challenge was the bureaucracy's unwillingness to implement new policies and uphold political promises. Policymaking involves a lengthy and complicated technocratic process. As such, although the governor had signed a political contract, his ability to uphold his promises were limited by the bureaucracy. New strategies were thus required.

After the election, JRMK faced three major challenges. First, Indonesia's bureaucracy is a highly sectoral. Housing and livelihood are cross-sectoral issues that involve the Office of Housing, Office of Public Works (i.e. infrastructure), Office of Social Affairs, and Office of Small Enterprises. This creates complexity on coordination among the two offices Second, the Indonesian bureaucracy tends to be elitist, citing "increased inefficiency" to justify its unwillingness to involve citizens in policymaking processes-even though non-participatory processes are ultimately more time consuming, requiring more negotiations and often failing to realise their goals. Third, the bureaucracy is oriented towards more pragmatic and administrative goals, seeking only to "do its job" rather than realise substantive empowerment.

Another legal challenge faced by members was the need to limit the content of the political contract to those areas that were under the purview of the Jakarta Provincial Government and reflected its duties and functions. This required members to identify existing policies as well as their budgets. Although new policies could be made, this would be a longer and more involved process than revising existing policies to reflect the Community Action Plan (CAP) desired by JRMK. Such CAPs were permitted under Regulation of the Minister of Public Works No. 06/PRT/M/2007 regarding Public Development and Spatial Planning, as well as under relevant bylaws (under the authority of the Office of Housing and Settlements). However, at the time the political contract was signed, the CAP registered with the provincial government was unclear. It offered not a programme, but a method. A new CAP was thus necessary for the political contract and to promote housing security. 
In order to use funds, JRMK proposed new guidelines for CAP. In this, it again collaborated with civil society elements such as ASF, University of Indonesia, and RCUS. Materials were not based in theory, but rather in the experiences of residents, architects, community organisers, and academics. CAP also tested its guidelines in the field and sought to ascertain the challenges and difficulties that could potentially occur.

After Anies Baswedan was inaugurated by President Joko Widodo on 16 October 2017, he required technical input regarding the urban planning process and the involvement of the urban poor. At the same time, civil society components sought to ensure that the Jakarta government promoted the interests of the urban poor (Kampung kumuh, 2019). The policymaking process was monitored by a team of civilians, backed by JRMK; political pressure was also applied.

The governor agreed to incorporate the CAP programme into the 2018 regional budget, which was formally inaugurated in mid-January 2018 (Taylor, 2018). Sixteen kampungs-all of which had signed a political contract with Anies Baswedanwere targeted by this programme: Akuarium, Lodan, Muka, Marlina, Gedung Pompa, Elektro, Kunir Pinangsia, Nelayan Kerang ljo, East Rawa, West Rawa, Tongkol, Krapu, Tembok Bolong, and Baru Tembok. This programme, however, was criticised by members of the Jakarta Parliament, who viewed the programme's budgetparticularly its consultant fees-as excessive (Prabowo, 2019)

To welcome the CAP programme, preparations were undertaken in every kampung. Nine kampungs received support from RCUS, four kamiongs received support from the University of Indonesia, and two kampungs received support from ASF. As of writing, consultants are continuing the CAP programme, albeit quite differently than initially planned (Residents criticize Anies, 2019).

\section{Conclusion}

This article has examined the political participation of the urban poor and their efforts to advocate for their housing and livelihood rights during Jakarta's 2017 gubernatorial election. Setting up is one of the strategies that urban poor movement utilizes to access their housing rights. The above discussion has offered three reasons for the signing of a political contract. First, the political contract was more legalistic and binding than that used unsuccessfully during Jakarta's 2012 gubernatorial election, being distinguished a) in its greater ability to apply pressure to politicians; b) in its involvement of broad networks of civil society actors; and c) in its concrete response to the continued threat of forced eviction under incumbent Basuki Tjahaja Purnama. JRMK may thus be identified as an "electoral movement", as argued by Tomsa and Setijadi (2018), as it used the momentum of the election to advocate for specific post-election policies.

Second, decision to use electoral strategy was chosen owing to the movement's materiality, particularly its focus on housing and livelihood rights; both of these were issues were related to land, a complex structural issue in Jakarta involving a multitude of economic and political actors. The movement recognised that previous regimes had employed a formal and legalistic approach, one that failed to promote the interests of the urban poor. Drawing on its previous experiences, 
particularly over the course of 2016, the movement also recognised that forced eviction would continue if the incumbent were re-elected. This complexity and urgency underpinned the urban poor movement in Jakarta.

Also important were the historical experiences of the urban poor, particularly in the previous decades. Through this historical struggle, the urban poor were able to develop broader networks than those who lacked such experience. These experiences also provided the urban poor with a knowledge base for choosing appropriate strategies and establishing consolidated networks with other civil society activists. The poor then expanded their networks further, enabling them to establish stronger coalitions.

Third, and related to the first argument, there were political opportunities for the urban poor to connect with the victorious gubernatorial candidate and monitor his policymaking and implementation. Such materiality was only available in Jakarta, not being available elsewhere in Indonesia. As such, this factor contributed to the materiality of the urban poor movement, its advocacy for housing and livelihood rights, and its strategies.

\section{References}

Abeyasekere, S. (1989). Jakarta: A history. Oxford University Press.

Ahuja, A., \& Chhibber, P. (2012). Why the poor vote in India: 'If I don't vote, I am dead to the state'. Studies in Comparative International Development, 47(4), 389-410. https://doi.org/10.1007/s12116-012-9115-6.

Arai, K. (2015). Jakarta 'since yesterday': The making of Post-New Order regime in an Indonesian Metropolis. Southeast Asian Studies, 4(3), 445-486. https://doi.org/10.20495/seas.4.3_445.

Aspinall, E., \& Sukmajati, M. (Eds.). (2014). Electoral dynamics in Indonesia: Money politics, patronage and clientelism at the grassroots. Singapore, NUS Press.

Baharoglu. D., \& Kessides. C. (2002). Poverty reduction strategy paper (PRSP) sourcebook, Chapter 6 : urban poverty. http://siteresources.worldbank.org/INTPRS1/Resources/3836061205334112622/4418_chap16.pdf.

Banks, N. (2008). A tale of two wards: Political participation and the urban poor in Dhaka city. $\begin{array}{llll}\text { Environment \& Urbanization, 361-376. } & \text { 20(2), }\end{array}$ https://doi.org/10.1177/0956247808096116.

Berenschot, W. (2010). Everyday mediation the politics of public service delivery in Gujarat, India. Development and Change, 41(5), 883-905. https://doi.org/10.1111/j.14677660.2010.01660.x.

Caraway, T.L., \& Ford, M. (2014). Labor and politics under oligarchy. In M. Ford., \& T. Pepinsky (Eds.), Beyond oligarchy? Critical exchanges on political power and material inequality in Indonesia (pp.139-155). Cornell Southeast Asia Program Publications. 
Dewi, S. W. (2014). First Kampung 'Deret' inaugurated. The Jakarta Post. jakartapost.com/news/2014/04/04/first-kampung-deret-inaugurated.html.

Ford, M. (2014). Learning by doing: Trade unions and electoral politics in Batam, Indonesia 2004-2009. South East Asia Research, 22(3), 341-357. https://doi.org/10.5367/sear.2014.0219.

Gibbings, S. L., Lazuardi, E., \& Prawirosusanto, K. M. (2017). Mobilizing the masses: Street vendors, political contracts, and the role of mediators in Yogyakarta, Indonesia. Bijdragen tot de Taal-, Land- en Volkenkunde, 173(2-3), 242-272. https://doi.org/10.1163/22134379-17301004.

Harriss, J. (2005). Political participation, representation and the urban poor: Findings from research in Delhi. Economic and Political Weekly, 40(11), 1041-1054.

Hutapea, E. (2019). Per Maret 2019, backlog rumah 7.6 juta unit. Kompas.com. https://properti.kompas.com/read/2019/03/11/104252821/per-8-maret-2019-backlogrumah-76-juta-unit?page=all.

Hutchison, J. (2007). 'Disallowed' political participation of Manila's urban poor. Democratization, 14(5), 853-872. DOI: 10.1080/13510340701635696.

Kampung kumuh di ibukota dan jurus 'naik kelas' era Anies. (2019, August 22). CNN Indonesia. https://www.cnnindonesia.com/nasional/20190806134147-20-418863/kampungkumuh-ibu-kota-dan-jurus-naik-kelas-era-anies.

Kusno, A. (2012). Housing on the margin: Perumahan Rakyat and the future urban form of Jakarta. Indonesia 94, 23-56. https://doi.org/10.5728/indonesia.94.0023.

Lawless, J., \& Fox, R. L. (2001). Political participation of the urban poor. Social Problems, 48(3), 362-385. https://doi.org/10.1525/sp.2001.48.3.362.

LBH Jakarta. (2017, April 13). Seperti puing: Laporan penggusuran paksa di wilayah DKI Jakarta tahun 2016. Bantuanhukum.or.id. https://www.bantuanhukum.or.id/web/seperti-puinglaporan-penggusuran-paksa-di-wilayah-dki-jakarta-tahun-2016/.

McAdam, D., \& Tarrow, S. (2010). Ballots and barricades: On the reciprocal relationship between elections and social movements. Perspectives on Politics, 8(2), 529-542. https://doi.org/10.1017/S1537592710001234.

Nelson, J. (1979). Access to power politics and the urban poor in developing nations. Princeton University Press.

Penggusuran waduk Pluit dimulai. (2013, May 20). BBC News Indonesia. https://www.bbc.com/indonesia/berita_indonesia/2013/05/130520_jakarta_waduk.

Prabowo, H. (2019, November 4). DPRD DKI kritik anggaran konsultan penataan kampung Rp 556 juta/RW. Tirto.id. https://tirto.id/dprd-dki-kritik-anggaran-konsultan-penataankampung-rp556-jutarw-ek8B.

Power from below: Gerakan perempuan miskin kota Makassar. (2017, January 2). Urban Poor Consortium. https://www.urbanpoor.or.id/artikel/power-from-below-gerakanperempuan-miskin-kota-di-makassar/9. 
Ramadhiani, A. (2017). Pemprov DKI dinilai tidak adil dalam penataan ruang. Kompas.com. https://properti.kompas.com/read/2017/02/14/172504021/pemprov.jakarta.dinilai.tid ak.adil.dalam.penataan.ruang.

Residents criticize Anies' 'Consultant Action Plan'. (2019, February 4). The Jakarta Post. https://www.thejakartapost.com/news/2019/02/04/residents-criticize-aniesconsultant-action-plan.html.

Savirani, A. (2017). Jakarta is still the oligarch's turf. New Mandala. https://www.newmandala.org/jakarta-still-oligarchs-turf/.

Savirani, A., \& Aspinall, E. (2018). Adversarial linkage: The urban poor and electoral politics in Jakarta. Journal of Current Southeast Asian Affairs, 36 (3), 3-34. https://doi.org/10.1177/186810341703600301.

Steijlen, F. (2004). Sutiyoso's re-election as Governor of Jakarta. Bijdragen tot de Taal-, Landen Volkenkunde, 158(3), 513-527. https://doi.org/10.1163/22134379-90003774.

Taylor, G. S. (2018, January 14). Anies luncurkan program CAP 16 Kampung. CNN Indonesia. https://www.cnnindonesia.com/nasional/20180114195055-20-268766/aniesluncurkan-program-cap-16-kampung-jakarta.

Tomsa, D., \& Setijadi, C. (2018). New forms of political activism in Indonesia: Redefining the nexus between electoral and movement politics. Asian Survey, 58(3), 557-581. https://doi.org/10.1525/as.2018.58.3.557.

Tunas, D., \& Peresthu, A. (2010). The self-help housing in Indonesia: The only option of the poor? Habitat International, 34(3), 315-322. https://doi.org/10.1016/j.habitatint.2009.11.007.

Weeks, D. (2014, January 10). Why are the poor and minorities less likely to vote. The Atlantic. https://www.theatlantic.com/politics/archive/2014/01/why-are-the-poor-andminorities-less-likely-to-vote/282896/.

Winarso, H. (1999). Private residential developers and the spatial structure of Jabotabek. In G. P. Chapman., A. K. Dutt., \& R. W. Bradnock (Eds.), Urban growth and development in Asia, Vol. 1: Making the cities (pp. 277-304). Ashgate. 